\title{
Reading through Photography: Roland Barthes's last seminar "Proust et la photographie"
}

\author{
Kathrin Yacavone, University of Edinburgh
}

\begin{abstract}
:
Focused on Roland Barthes's notes for the last seminar of his Collège de France lecture series, entitled "Proust et la photographie," this article considers the later Barthes's conceptions of reading and writing, arguing that they are closely intertwined with his reflections on photography. Marcel Proust is cast as the paradigmatic author in Barthes's post-1968 critical writing, in which he serves as both an exemplar for the complex process of transforming life into literature and as a figure of profound identification for Barthes the would-be novelist. À la recherche du temps perdu is a clear case of a literary work informed by its author's life that at the same time denies or problematises straightforward autobiography. For Barthes the experience and study of Proust's masterpiece entails a play with autobiographical 'clefs' that can be considered an activity on the part of Barthes's pleasure-seeking reader, one that has significant theoretical implications regarding the apprehension of any literary text. As analysis of "Proust et la photographie" and $L a$ Chambre claire reveals, the photograph for Barthes signifies the oscillation between the imaginary and the real, fiction and (auto)biography, that characterises both literary authorship and readership.
\end{abstract}

The posthumous publication of Roland Barthes's Collège de France lectures and seminars (delivered between 1977 and 1980) has triggered a new interest among scholars in Barthes's late $e u v r e .{ }^{1}$ His last seminar, however, entitled "Proust et la photographie" one Barthes never delivered owing to his fatal accident on the Rue des Écoles in early $1980^{3}$ - has to this point received surprisingly little scholarly attention. ${ }^{4}$ The seminar's subtitle, "Examen d'un fonds d'archives photographiques mal connu," is with hindsight ironically appropriate: although the photographs that Barthes refers to are much more widely known today, especially among Proust scholars (due in part to the 1978 exhibition of these images and the subsequently revised publication of the exhibition catalogue, $L e$ monde de Proust vu par Paul Nadar edited by Anne-Marie Bernard), ${ }^{5}$ Barthes's text remains largely 'mal connu.' Published as an appendix to the last volume of the Cours et séminaires au Collège de France series (the 2003 La Préparation du roman), the bulk of "Proust et la photographie" consists of fragmentary notes. There is an introduction, however, in which Barthes lays out the concepts that he wishes to address during the course of the seminar, followed by a large collection of photographic material - primarily late nineteenth-century portraits of Proust's family, friends, and acquaintances taken by Paul Nadar, the son of the famous Felix Nadar - accompanied by short biographical notes on each person represented and his or her connection to Proust and his monumental $\grave{A}$ la recherche du temps perdu.

The incompleteness of "Proust et la photographie" notwithstanding, I would like to suggest that a close reading of this text sheds new light on a number of central themes with which Barthes's late writings are deeply concerned. Firstly, it expands on issues pertaining to the relation between authorship and the reception of literary works from an angle that may be surprising to the reader more familiar with Barthes's earlier conception of the author, as precipitated in his seminal 1968 essay "La mort de l'auteur," and yet is consistent with the perspective on these issues found in other lectures and seminars 
delivered at the Collège de France. Secondly, "Proust et la photographie" reflects on the complex relation between photography, the imaginary, and the real, in a way that can be provocatively juxtaposed with Barthes's last book on photography La Chambre claire, Note sur la photographie, written in 1979, shortly before the seminar on Proust was prepared.

This essay has a double objective: it will attempt to explicate a number of the concepts forwarded in "Proust et la photographie" as a freestanding work, and it will also view this text from an historical and contextual perspective with reference to Barthes's late critical project, more generally. It will become clear that in discussing photographic portraits in close conjunction with a specific type of reading, one which Barthes's calls his "Marcellisme" (391) as rooted in his identification with Proust the writer, on the one hand, and Marcel the narrator of La Recherche, on the other, Barthes subtly intertwines his own idiosyncratic interpretation of La Recherche with a new theory of reading that hinges on the reciprocal relationship between reality, in the form of biographical information, and the imaginary, associated with fictional narrative. I shall argue that it is the double function of the photograph as both evidence of the real and, at the same time, a starting point for a flight of imagination on the part of its beholder, that foregrounds an engagement with literature for which Barthes's reading of La Recherche paradigmatically stands.

\section{The desire to write and 'moments de vérité'}

It has often been acknowledged that Proust and his $\grave{A}$ la recherche $d u$ temps perdu play a significant, if paradoxical, role in Barthes's œuvre: Proust is omnipresent in Barthes's writing, yet his work was never the object of direct critical analysis. ${ }^{6}$ Although his comments on Proust are still largely parenthetical in Barthes's late texts, dating from the mid-to-late 1970s, the French novelist emerges as a powerful intellectual influence and as a model writer upon whom Barthes projects his literary ambition as well as aspects of his personal life. While this identification can be seen as a secretive leitmotif of Barthes's engagement with Proust throughout his career, it was only after Barthes turned to a specific 'writerly' practice of reading, namely one rooted in the pleasure-seeking subject as discussed in, and exemplified by, Le Plaisir du texte (1973), that Barthes's identification with Proust finds a theoretical justification in his work. In his 1978 lecture "Longtemps, je me suis couché de bonne heure," delivered shortly before the beginning of the Préparation $d u$ roman series, besides acknowledging that an identification with a fictional character is quite a common 'readerly' response to a novel, Barthes also draws attention to the more exceptional case of the reader who "veut lui-même écrire une œuvre"" :

Proust est le lieu privilégié de cette identification particulière, dans la mesure où $L a$ Recherche est le récit d'un désir d'écrire: je ne m'identifie pas à l'auteur prestigieux d'une œuvre monumentale, mais à l'ouvrier, tantôt tourmenté, tantôt exalté, de toute manière modeste, qui a voulu entreprendre une tâche à laquelle, dès l'origine de son projet, il a conféré un caractère absolu. ${ }^{8}$

A modest identification with a tormented writer then, as opposed to a pretentious selfcomparison with a famous author, or, as Barthes asserts, identification with "Marcel" rather than "Proust.",

Barthes's idiosyncratic identification with Proust bound to his desire to write further underscores the existential dimension of his Proust reading by virtue of the fact that both are related to what Barthes calls, following Dante, his "Vita Nova." "For Barthes the writer, such a 'new life' is linked to "une nouvelle pratique d'écriture," 11 and, as 
Barthes was well aware, for Proust the new practice of writing (which became $L a$ Recherche) also coincided with a 'new life' (albeit one behind closed doors and drawn curtains, as we know). Yet Barthes's reading of La Recherche involves another response, one which is more affective and closely aligned to pathos in the etymological sense of the word, that is, a more traditional empathetic identification with the narrator of $L a$ Recherche, rather than with its author. The subject of this identification is not the novel as a whole, in its general structure or design, but a particular episode in its represented world, namely the beginning of the second part of Le Côté de Guermantes, when the narrator returns from the Champs-Élysées with his grandmother who just had an attack of illness foreshadowing her imminent death, which Barthes views through the prism of his mother's death. Barthes introduces an expression for such literary episodes that affect the reader in a visceral way; calling them, emphatically, "moments de vérité." 12 These 'moments de vérité' in La Recherche, are those points at which life and literature meet, reinforcing Barthes's sense that, as he says in an interview given in the context of the publication of Le Plaisir du texte, for him Proust has written not only a novel but a handbook for life. ${ }^{13}$ Since these 'moments de vérité' are rooted in the reader's affective response, they prompt Barthes to argue that pathos can be a powerful tool of critical interpretation. He writes:

Le 'moment de vérité,' à supposer qu'on accepte d'en faire une notion analytique, impliquerait une reconnaissance du pathos, au sens simple, non péjoratif, du terme, et la science littéraire, chose bizarre, reconnaît mal le pathos comme force de lecture. ${ }^{14}$

However, Barthes is not only a reader identifying with Marcel, the narrator of $L a$ Recherche, but also with Marcel, the writer of it, giving this 'pathetic' reading an even stronger existential dimension.

This theme of identification thus draws attention to the structure en abyme, marking the relation between life and literature that Barthes explores more thoroughly in his last lecture series at the Collège de France, La Préparation du roman, the first part of which is programmatically called "De la vie à l'œuvre." Here Barthes returns to the notion of 'moment de vérité,' this time in the context not only of his own desire to write a literary work (neither essay nor novel, but what he refers to as a "tierce forme" ${ }^{15}$ ) but in preparation to do so. It is again (or still) Proust who is seen as the paradigmatic writer, despite the fact that Barthes frequently evokes other authors, including Gustave Flaubert, Franz Kafka, Chateaubriand, and James Joyce. Among these authors, Barthes singles out Joyce and Proust and draws attention to their respective writerly techniques for 'passing' from life to literature (Barthes refers to such techniques as "passeurs" [151]): "la quiddité" in one case and "la vérité" in the other (ibid.). While, for Barthes, Joyce's notion of epiphany is the "soudaine révélation de la quiddité (Whatness) d'une chose" (ibid), Proust exemplifies a different means by which the facticity or truth of the writer's life is transformed into a literary or artistic truth. Barthes writes:

avec Proust, il ne s'agit pas, du moins en première ligne, de la quiddité des choses, mais de la vérité de l'affect $\rightarrow$ parenté cependant [...]: pour moi une sorte de propédeutique à ce que j'appelle [...]: le Moment de vérité. (155)

In opposition to Barthes's earlier discussion of 'moments de vérité' from the point of view of the reader, i.e. reception (in "Longtemps, je me suis couché de bonne heure"), they are here also aligned with the writer, or, more precisely, with the one who wants to write, that is, with (literary) production. 


\section{Proust as 'biographologue' and Barthes's 'Marcellisme'}

Barthes perceives of the Proustian 'vérité de l'affect' as a channel, so to speak, by which life becomes literature, from the perspective of the author (as distinct from the 'moments de vérité' associated with the reader's unique existential response to the work through pathos etc.). Although Barthes certainly does not limit the reader's experience of the work to the author's life or intentions, he does clearly suggest, in accordance with the orientation of his later work, an important link between that life and the genesis and the nature of the work, a link which cannot be ignored. And of course these considerations are particularly relevant to, and problematised by, the pronounced autobiographical aspects of La Recherche. Given this, does Barthes then view La Recherche as Proust's autobiography? In what can be seen as an answer to this question Barthes explains:

\footnotetext{
Proust, c'est l'entrée massive, audacieuse de l'auteur, du sujet écrivant, comme biographologue, dans la littérature; l'œuvre qui ne relève pas du genre biographique (Journal, Mémoires), est entièrement tissée de lui, de ses lieux, de ses amis, de sa famille; à la lettre, il n'y a que cela dans son roman - malgré tous les alibis théoriques: condensations, absence de clefs, etc. (278)
}

Barthes here introduces Proust as 'biographologue,' a neologism derived from his earlier coinage of 'biographème' in the preface of his study on Sade, Fourier, Loyola (1971), a term which refers to the dispersion of one's biography into individual moments and details (in opposition to a chronological and teleological succession of events, which is a biography or autobiography proper). ${ }^{16}$ Whereas 'biographème' designates an inherently fragmentary biographical account of one's life, 'biographologue' is the writer of such an account, as a fragmented subjectivity. La Recherche is thus not autobiography but a new écriture, based on the principle of "la division, la fragmentation, voire la pulvérisation du sujet" as Barthes emphatically suggests (279), i.e. based on a "scattered" subject. ${ }^{17}$

This new 'écriture biographique' that Barthes discovers, ultimately through his writerly identification with Proust and the project of La Recherche, is different from traditional (auto-) biographical writing not only in relation to this different 'je' that speaks, but also with regards to the relation between reader and this "Écriture de Vie" (ibid.). In other words, despite the fact that La Recherche is interwoven with Proust's biography, it is simply impossible, and also not desirable, to attempt a definitive reconstitution of Proust's life through his literary cuvre (or vice versa). Yet, at the same time, in "Proust et la photographie" Barthes appears to be suggesting a type of reading and literary interpretation (of La Recherche) that is crucially informed by photographic material that invites a factual and biographical approach owing to the photograph's indexical nature as the real past captured and preserved. ${ }^{18}$ How then does Barthes bring these two opposites together? How does he reconcile his rejection of a positivist approach to literature, which he characterises as "vain, dérisoire et presque ridicule" (395), and his pedagogical use of photographic portraits of real people that are known to have served Proust as models for his characters (albeit not always in a straightforward fashion)? To answer these questions it is necessary to turn to the two theoretical assumptions with which Barthes introduces his seminar, that is, after explaining that it is "ni sur la Photo, ni sur Proust, mais sur 'Marcel"' (391). The first assumption pertains to "le "monde' de Proust (= de Marcel)" (392), which is an allusion to the title of the 1978 Nadar exhibition, Le Monde de Proust: photographies par Paul Nadar.

Drawing on what can be established concerning Proust's social-economic background (such as the social status of Proust's parents), Barthes underlines the difference between the " "monde' mondain (classes très supérieures)" (393), i.e. the social milieu that Proust is most notably concerned with in his Recherche, and the environment 
in which he grew up. Barthes also returns to a central question that has occupied him since the mid-to-late 1960s, namely the question of what objective and subjective factors gave rise to La Recherche. ${ }^{19}$ Here he addresses the issue from a psychological perspective, arguing that La Recherche exemplifies the greatest literary paradox inasmuch as "l'œuvre la plus haute du $\mathrm{XX}^{\mathrm{e}}$ siècle soit partie de (ait été déterminée par) ce qui peut être ailleurs le plus bas, le moins noble des sentiments: l'envie de promotion sociale" (ibid.). Paralleling his own 'désir d'écrire' with Proust's "désir social" (394), Barthes proposes that the Nadar portraits he intends to show to his audience (consisting of "Marcelliens," as he hopes [391]) reflect this issue in a number of ways. The three specific "pistes de déchiffrement (de lecture)" pointing towards social themes resonate with some of Barthes's earlier semiotic observations found in his 1957 Mythologies, in that he draws attention to the "trace sociale classique," signified by, firstly, fashion and clothes (394), secondly, the pose that is coded by photographic iconography corresponding to the social status of the depicted person, and, finally, in allusion to Pierre Bourdieu's then recently published book La Distinction, Barthes also suggests his audience pay close attention to the morphology of the faces of the photographed persons.

\section{La Recherche as 'roman à clefs'}

Moving beyond semiotics, the second preliminary theoretical assumption pertains to what Barthes perceives as a problematic generic categorisation of the roman à clefs, or the 'key novel,' in which actual persons appear as fictitious characters, and is closely aligned with his subsequent discussion of the photographs. It is in this context that Barthes's thesis concerning authorship, namely the 'biographologue' that he sees exemplified by Marcel Proust, finds its complement in a particular form of reading and interpretation. Making use of photographic portraits of Proust and his contemporaries, Barthes provocatively provides material for the very sort of biographical interpretation of La Recherche that he dissociates from his own critical practices as an end in itself, characterising them as both ineffective and ultimately futile. However, he acknowledges that Proust himself complicates a straightforward rejection of the roman à clefs since he himself dealt with this matter in a ambiguous and contradictory way. ${ }^{20}$ For instance, shortly before his death in 1922, Proust wrote a letter to Laure Hayman, who had previously accused him of taking her as a model for Odette in La Recherche, and Barthes quotes this letter in his notes accompanying her portrait. In response to Hayman's accusations, Proust states:

\footnotetext{
je suis forcé de vous répondre pour protester une fois de plus, sans plus de succès, mais par sentiment de l'honneur. Odette de Crécy non seulement n'est pas vous, mais est exactement le contraire de vous. (432)
}

Barthes also points out that Proust acknowledged some 'clefs,' such as, for instance, Agostinelli for Albertine, Montesquiou for Charlus, or the house of Tante Léonie in Combray for the novelistic version of the place where the Proust family spent their summers in Illiers.

It is important to note that Barthes offers a perceptive critique of simplistic one-toone biographical interpretations of literary works in the hope of rescuing or defending more profound links between the real and the fictional. Barthes argues that an approach to Proust's Recherche along the lines of a roman à clefs is problematic in that such a method implies an array of axiomatic assumptions, such as a Platonic notion of literature as copy of the real. And yet he appropriates some of the assumptions inherent in such a reading (i.e. the search for the real-life character disguised under a fictitious name) and gives them a new twist. Barthes stresses that the sheer scope of La Recherche renders an exhaustive tracing of such keys impossible and moreover distracts from the more important issue of 
reading Proust's novel: "la cryptologie de ce monde serait à la fois impossible et hors proportion avec l'enjeu réel, qui est la lecture" (396). At the same time, he celebrates such a reading as an example, or, rather, symptom, as we shall see, of the fluid and inexhaustible interpretative dynamic between text and reader, one in which the reader's "énergie cryptologique" is pleasurably played out (ibid.). Accordingly, Barthes's seminar "Proust et la photographie" invites us to play the "jeu des clefs" (ibid.), but in a more subtle fashion than does Proust biographer George Painter, whom Barthes accuses of abusing such keys. In fact, already in 1966 in his review of Painter's biography, programmatically entitled "Les vies parallèles," Barthes resolutely rejects the idea of a one-way reading of literary work and biography in favour of a parallel reading in which both reciprocally illuminate each other. In harmony with his last seminar under discussion here, Barthes argues in his review that it is "vain de chercher les 'clefs' de la Recherche. Le monde ne fournit pas les clefs du livre, c'est le livre qui ouvre le monde." 21

While Barthes in 1966 draws attention to a concept of écriture that conjoins both literary and biographical work, in 1980 he puts greater emphasis on the reader. Thus he notes in "Proust et la photographie" that "les clefs ne renvoient pas à Proust mais au lecteur; les clefs, le désir, le plaisir des clefs est un symptôme de la lecture" (396). Rather than a goal, Barthes views the pursuit of 'clefs' as an indication of the reading process that Proust's Recherche simultaneously stimulates and problematises. Biographical clues are seen to function as a perpetual starting point for reading, a notion that Barthes wished to develop into a more comprehensive theory of how a reader engages with a narrative work with regards to the imaginary. He forwards this notion in an intuitive fashion, explaining:

les Clefs sont de l'ordre du leurre, mais ce leurre fonctionne comme une Plus-Value de la Lecture, elles affermissent et développent le lien imaginaire à l'Euvre; elles font partie d'un objet théorique à poser [...]. C'est à ce titre que nous ne refoulerons pas le problème des Clefs, car le leurre est le fondement même de la lecture. (Ibid.)

It is the reader's imagination, or "l'Imaginaire" (ibid.), which connects the fictitious and the real character, drawing on a "Technique de la Condensation," as Barthes writes (ibid.). Barthes re-emphasises that it is the reader rather than Proust who identifies the heterogeneous traits of the fictive personage with those of a real person: "au-delà de Proust, c'est nous qui condensons, c'est nous qui rêvons" (ibid.). It is at this point in the seminar, while reflecting on the reader's identification of a novelistic character with a contemporary of Proust, that Barthes establishes a significant connection with photography.

\section{Reading through photography}

In "Proust et la photographie" Barthes argues that Nadar's portrait photographs of Proust's family, friends, and contemporaries both help and hinder the process that he describes as 'condensation,' i.e. the reader's matching of literary 'clefs' with real-life people: the photograph "aide et gêne cette condensation - ce rêve" (ibid.). The assertion that the photograph both aides and inhibits the exercise of the reader's imaginative engagement with the text recalls Barthes's arguments in La Chambre claire, where the photographic image is characterised as potentially both 'Proustian' and 'anti-Proustian' depending on whether or not it triggers an involuntary memory in the photograph's beholder. ${ }^{22}$ Yet in contrast to his last book on photography, where the imaginary process involved in, and triggered by, the photograph is clearly linked to the viewer's personal life-experience in relation to the depicted person, in Barthes's last seminar on Proust and photography, the imaginary is the hinge, as it were, between the photograph and the literary work, or, more specifically, between the real-life person and the character in Proust's Recherche. As the 
notion of 'condensation' hints at, Barthes is keen to point out that this correspondence is not a direct and given one. Instead it emerges in four principal ways, as a result of the four types of 'clefs' that Barthes distinguishes. The first type is based on physical resemblance. Barthes's example is the photograph of the Marquis Boni de Castellane which he glosses by noting: "Très proche de Saint-Loup: élégante silhouette, teint rose plein d'éclat, yeux froids de lapis-lazuli, peau blonde [...]" (413). To this 'clef,' one that Barthes suggests occurs rather rarely, he adds the "clefs parcellaires" (396), the example being the monocle of Comte Louis de Turenne that can be seen on his portrait and which reappears in $L a$ Recherche as owned by Bréauté (449), and "clefs' "situationnelles" (396), such as Marie Benardaky, whom Proust fell in love with after seeing her on the Champs-Élysées. Despite the fact that she does not resemble Gilberte physically, this episode is found in $L a$ Recherche, where the narrator is captivated by Gilberte upon seeing her on the same street (407). Finally there are 'clefs' "structurales" (396), for example Madame Benardaky, who "n'est Odette que par la place structurale" (405), that is, she is Marie's mother and yet not Odette.

This classification is not as neat as it may appear. For Barthes draws attention to the fact that the autobiographical 'clefs' can be misleading and contradictory, as one might expect. Thus, in contrast to Lydie Aubernon de Nerville who figures as the personnage à clef for Madame Verdurin and that Barthes characterises as "l'une des clefs les plus homogènes et les plus probantes" (401), there is an "[a]berration des clefs" (406) pertaining to Monsieur Nicolas Benardaky since he is Marie Benardaky's father, yet "[c]e gros homme obtus et vulgaire" cannot be reconciled with Proust's literary depiction of Swann (ibid.). Barthes plays this "jeu des clefs" (396) for all 56 alphabetically ordered real-life persons of whom he includes at least one photographic portrait. As in the rest of his Collège de France lectures, in his biographical glossing of the Nadar photographs Barthes uses symbols and abbreviations $(=, \neq, \rightarrow,:,+$, cf.) rather than conjunctions or phrases in order to logically connect the elliptical notes that were meant to supplement his seminar presentation. ${ }^{23}$ In the context of "Proust et la photographie" these codes are straightforward inasmuch as they indicate whether a biographical detail of the photographed person matches a character in the Recherche $(=$ or $\rightarrow)$, or whether it does not $(\neq)$, for instance. Yet the question remains as to the particular relationship between the type or theory of reading (Barthes's 'Marcellisme') at issue, and the double function of the photograph (as simultaneously aiding and disturbing or distracting the reader's imagination), in the context of this game of keys and analogies that link life and literature.

Following Barthes's theoretical reflections on the photographic image as a framing and freezing of the real in La Chambre claire and elsewhere and hence its characteristic "effet de réel" (to borrow the title of his 1968 article), it is not surprising that in "Proust et la photographie," he argues that the photograph "va fonctionner comme un affrontement du Rêve, de l'Imaginaire de lecture, au Réel" (397). The photograph is here opposed to the imaginary involved in the process of reading and, more specifically, to the creative process at work in indentifying real people and situations with fictive ones which Barthes's describes as the core activity of deciphering the 'keys' of Proust's novel, as I have noted. Accordingly, there are only a few portraits that in Barthes's view "collent au personnage (ne le gênent pas)" (ibid.), most notably the photograph of Charles Haas that Barthes comments as follows: "= Swann (celui-ci: ne gêne pas l'image) [...] Tout le monde reconnut Swann-Haas" (430). This rare exception notwithstanding, the majority of photographs assembled by Barthes are seen to disappoint, that is, to not correspond in any powerful or interesting way with the mental image evoked by the literary depiction of a character. Barthes notes with respect to the portrait of Maurice Barrès who has a trait of Bergotte that "on ne peut rien induire, on ne peut surimprimer" (402), an affirmation resonating with his observation in La Chambre claire that the "Tout-Image" of 
photography is opposed to the "Peu-d'Image" of reading, by virtue of the fact that the "image photographique est pleine, bondée: pas de place, on ne peut rien y ajouter."

However, as I hinted at earlier, if some characteristics of the photographic image seem to obstruct and hinder the imaginative dynamics of reading and interpreting literature, it is also, at the same time, apt to trigger a process of imaginary wandering or free contemplation in the viewer. Barthes's comments on the Nadar photographs testify to this latter type of response insofar as they relate first and foremost to his personal viewing of the images, as is the case with respect to his commentary on selected photographs in $L a$ Chambre claire. For instance, the childhood photographs of Jeanne Pouquet (the 'clef' for Gilberte) and Gabrielle Schwartz exercise their proper visual power, reminding Barthes of the "époque de l'enfance de ma mère" (444) in a way distinct from Proust's literary description of the same time period (i.e. the late nineteenth century). This effect of, or response to, the photograph, of the type that Barthes in La Chambre claire famously calls the punctum, is the paradoxical figure of that which is both already there in the photograph and that which the viewer adds to it. ${ }^{25}$ Thus Barthes's seminar notes on the photographs by Nadar in relation to La Recherche and, concomitantly, on the process of viewing the images themselves, evidences the fact that the imaginary is always already 'active' while viewing photographs, inasmuch as they display a high degree of interpretation, association, and addition that cannot be reduced to the photographic image or to the literary depiction of the photographed person by Proust.

This interpretation is in accord with Barthes's more general observation at the beginning of the seminar when he declares that "il y a une emprise de ces Photos: nous rêvons, donc nous transférons" and hence "nous sommes frustrés quand un personnage de La Recherche n'a pas sa photo" (397). As Brassaï notes in his 1997 book Marcel Proust sous l'emprise de la photographie, Proust himself was enthralled by photographs of his friends and acquaintances, and Barthes, who is well aware of this fact, intends to reproduce this "intoxication" 26 that the original photographs had on Proust, and that Barthes himself experiences, for his audience: 'L'objectif du séminaire n'est pas intellectuel: c'est seulement de vous intoxiquer d'un monde, comme je le suis de ces photos, et comme Proust le fut de leurs originaux" (391). It is the last few photographs that Barthes reproduces and comments on, the ones of Proust and his family, that ultimately seal this intoxication inasmuch as Barthes places en abyme not only the photographically depicted person and the character in La Recherche, but also his own life and that of Proust (resonating Barthes's discourse on his identification as problematised explicitly in 1978). Paradoxically, it is the photograph of Proust's grandmother, Adèle Weil, that for Barthes represents an "abîme entre la réalité et la littérature" (451), echoing ex negativo the mise en abyme of his own desire to write with that of Proust and the narrator of La Recherche, which is, in Barthes's view, inevitably related to the death of their respective (grand)mothers. Yet, if the photograph in this case functions as the potential matrix between reality and literature, it is reasonable to assume that it is part of both worlds, so to speak: neither purely real nor exclusively fiction. Indeed, just as Barthes returns to the notion of authorship in the form of a 'biographologue' via Proust, as I have suggested, the photograph here functions as a "biographème" 27 that the reader, through a process of imaginary contemplation, relates to the fictional world of La Recherche as well as to his or her own world. However, if the photograph in La Chambre claire incites writing (i.e. the writing of the book itself), Barthes's intention in "Proust et la photogarphie" is that the photograph incites reading. ${ }^{28}$ It is what draws one into the world of both Proust and Marcel and it is capable of inviting both a reading of La Recherche and of Proust's life, by virtue of its double function with respect to this reading.

Barthes's last seminar thus not only compels us to read his other work in a new light, by virtue of its novel reflections on his perennial concerns with the nature of 
authorship and the process of reading, but also incites us to re-read La Recherche, following our own instincts, fantasies, and pleasures. Therefore, even if Barthes sadly never had the opportunity to 'intoxicate' his audience at the Collège de France with the Nadar photographs of Proust and his family and acquaintances, and his comments on them, the reader of his seminar notes is enriched by this word mediated encounter with Marcel Proust, the man and the writer of $\grave{A}$ la recherche $d u$ temps perdu, and with his real and an imagined worlds.

\section{Notes}

${ }^{1}$ See for example: Jürgen Pieters and Kris Pint eds. Roland Barthes Retroactively. Reading the Collège de France Lectures, Paragraph 31.1 (2008) and Harri Veivo ed. Semiotics of Roland Barthes, Sign Systems Studies 36.1 (2008).

${ }^{2}$ Roland Barthes. "Proust et la photographie. Examen d'un fonds d'archives photographiques mal connu." La Préparation du roman I et II. Cours et séminaires au Collège de France (1978-1979 et 1979-1980), ed. Nathalie Léger, Paris: Seuil/IMEC, 2003, 385-457. Hereafter parenthetical references in the text are to this edition.

${ }^{3}$ In fact, this accident took place on the night of Feb. $25^{\text {th }}$, immediately following Barthes's visit to the Collège de France to check the slide projector that he would have needed for the first session of the seminar.

${ }^{4}$ To my knowledge the only discussion of these notes is Jérôme Prieur's "Dispositives: Barthes, Proust, Nadar." R/B Roland Barthes, ed. Marianne Alphant and Nathalie Léger, Paris: Seuil, 2002, 113-115. (None of the publications referred to in footnote 1 mention the seminar "Proust et la photographie".)

${ }^{5}$ Anne-Marie Bernard ed. Le monde de Proust vu par Paul Nadar, Paris: Éditions du Patrimoine, 1999.

${ }^{6}$ Cf. for instance: Éric Marty. "Marcel Proust dans 'la chambre claire'." L'Esprit Créateur 46.4 (2006): $125-$ $133,125$.

${ }^{7}$ Roland Barthes. "Longtemps, je me suis couché de bonne heure." Euvres complètes, 5 vol., ed. Éric Marty, Paris: Seuil, 2002, vol. 5, 459.

${ }^{8}$ Ibid.

${ }^{9}$ Ibid., 464-465.

${ }^{10}$ Ibid., 467.

${ }^{11}$ Ibid.

${ }^{12}$ Ibid., 468.

${ }^{13}$ Barthes explains that "Proust, c'est un système complet de lecture du monde" and that "[1]e plaisir de lire Proust $[\ldots]$ tient donc $[\ldots]$ d'une consultation biblique." Barthes. "Roland Barthes contre les idées reçues." CEuvres complètes, vol. 4, 569.

${ }^{14}$ Barthes. "Longtemps, je me suis couché de bonne heure." Euvres complètes, vol. 5, 468.

${ }^{15}$ Ibid., 461.

${ }^{16}$ Barthes writes in the preface to Sade, Fourier, Loyola: "si j'étais écrivain, et mort, comme j' aimerais que ma vie se réduisît, par les soins d'un biographe amical et désinvolte, à quelques détails, à quelques goûts, à quelques inflexions, disons: des 'biographèmes', dont la distinction et la mobilité pourraient voyager hors de tout destin et venir toucher, à la façon des atomes épicuriens, quelques corps futur, promis à la même dispersion; une vie trouée, en somme, comme Proust a su écrire la sienne dans son œuvre." Barthes. Sade, Fourier, Loyola. Euvres complètes, vol. 3, 706.

${ }^{17}$ I borrow this expression from Malcolm Bowie who argues that Proust in Barthes's writings is a "scattered Proust.” Malcolm Bowie. "Barthes on Proust.” The Yale Journal of Criticism 14 (2001): 513-518, 514.

${ }^{18}$ Despite the fact that chronologically Barthes's writings on photography move from semiotic analysis to phenomenological description, his reflections remain deeply rooted in a realist notion of the medium i.e. that the photograph captures a moment of the real past.

${ }^{19}$ In his 1967 essay "Proust et les noms," Barthes contemplates this subject and returns to it in his 1979 article "Ça prend."

${ }^{20}$ Some of Proust's most famous and explicit comments on this subject, such as his assertion "[...] il n'y a pas de clef pour les personnages de ce livre [La Recherche]; ou bien il y en a huit ou dix pour un seul," are quoted in Bernard ed. Le monde de Proust, 14 and 23.

${ }^{21}$ Barthes. "Les vies parallèles." Euvres complètes, vol. 2, 813. 
${ }^{22}$ Although Barthes famously argues that there is "rien de proustien dans une photo," he nonetheless leaves no doubt about the fact that the rediscovery of a childhood photograph of his late mother "me donnait un sentiment aussi sûr que le souvenir, tel que l'éprouva Proust." Barthes. La Chambre claire. Euvres complètes, vol. 5, 855 and 845. Cf. for a more detailed analysis: Kathrin Yacavone. "Barthes et Proust: La Recherche comme aventure photographique." Fabula. Littérature, histoire, théorie 4: L'écrivain préféré (March 2008): http://www.fabula.org/lht/4/Yacavone.html.

${ }^{23}$ Cf. Jürgen Pieters and Kris Pint. "An unexpected Return: Barthes's Lectures at the Collège de France." Roland Barthes Retroactively, 3.

${ }^{24}$ Barthes. La Chambre claire. Euvres complètes, vol. 5, 861.

${ }^{25}$ Barthes writes in La Chambre claire that the punctum is "un supplément: c'est ce que j'ajoute à la photo et qui cependent y est déjà." Ibid., 833.

${ }^{26}$ As Marielle Macé has pointed out, Barthes borrows this word from the Proustian narrator who declares about himself that he is "intoxiqué" by Albertine. Marielle Macé: "Selon l'écrivain préféré." Fabula. Littérature, histoire, théorie 4: L'écrivain préféré (March 2008): http://www.fabula.org/lht/4/Mace.html, 47.

${ }^{27}$ Barthes. La Chambre claire. Euvres complètes, vol. 5, 811.

${ }^{28}$ Guillaume Perrier kindly drew my attention to the fact that the verb 'to incite' resonates with a Proustian term that he coined in "Journées de lecture" when he writes that "beaux livres [...] pour l'auteur [...] pourraient s'appeler 'Conclusions' et pour le lecteur 'Incitations'." Marcel Proust. "Journées de lecture." Contre Sainte-Beuve, précédé de Pastiches et mélanges et suivi de Essais et articles, ed. Pierre Clarac, Paris: Gallimard (Bibliothèque de la Pléiade), 1971, 160-194, 176.

\section{Bibliography}

Barthes, Roland. Euvres complètes, 5 vol., ed. Éric Marty, Paris: Seuil, 2002.

—. La Préparation du roman I et II. Cours et séminaires au Collège de France (19781979 et 1979-1980), ed. Nathalie Léger, Paris: Seuil/IMEC, 2003.

Bernard, Anne-Marie ed. Le monde de Proust vu par Paul Nadar, Paris: Éditions du Patrimoine, 1999.

Bowie, Malcolm. "Barthes on Proust." The Yale Journal of Criticism 14 (2001): 513-518.

Brassaï. Marcel Proust sous l'emprise de la photographie, Paris: Gallimard, 1997.

Compagnon, Antoine. "Proust et moi." Autobiography, Historiography, Rhetoric: Essays in Honour of Frank Paul Bowman, ed. Mary Donaldson-Evans et al., Amsterdam: Rodopi, 1994, 59-73.

Macé, Marielle: "Selon l'écrivain préféré." Fabula. Littérature, histoire, théorie 4: L'écrivain préféré (March 2008): http://www.fabula.org/lht/4/Mace.html

Marty, Éric. "Marcel Proust dans 'la chambre claire'." L'Esprit Créateur 46.4 (2006): 125-133.

Pieters, Jürgen and Kris Pint eds. Roland Barthes Retroactively. Reading the Collège de France Lectures, Paragraph 31.1 (2008).

Prieur, Jérôme. "Dispositives: Barthes, Proust, Nadar." R/B Roland Barthes, ed. Marianne Alphant and Nathalie Léger, Paris: Seuil, 2002, 113-115.

Proust, Marcel. À la recherche du temps perdu, 4 vol., ed. Jean-Yves Tadié, Paris: Gallimard (Bibliothèque de la Pléiade), 1987-1989.

-. "Journées de lecture." Contre Sainte-Beuve, précédé de Pastiches et mélanges et suivi de Essais et articles, ed. Pierre Clarac, Paris: Gallimard (Bibliothèque de la Pléiade), 1971, 160-194.

Veivo, Harri ed. Semiotics of Roland Barthes, Sign Systems Studies 36.1 (2008).

Yacavone, Kathrin. "Barthes et Proust: La Recherche comme aventure photographique." Fabula. Littérature, histoire, théorie 4: L'écrivain préféré (March 2008): http://www.fabula.org/lht/4/Yacavone.html. 